Беляченко В. В., (ORCID: 0000-0003-3938-5158); Педан Ф. Ф., $\quad$ (ORCID: 0000-0002-1132-089X); Романченко О. A., (ORCID: 0000-0003-1640-853X)

Центр воєнно-стратегічних досліджень Національного університету оборони України імені Івана Черняховського, Київ

\title{
Підходи до створення, підтримки і вдосконалення АСУ логістичного забезпечення ЗС України з урахуванням досвіду країн-членів НАТО
}

\begin{abstract}
Резюме. У статті розглянуто проблеми та шляхи вирішення завдань 1.4.6 та 1.4.8 Стратегічного оборонного бюлетеня на підставі досвіду країн-членів НАТО щодо створення інтегрованої автоматизованої системи управління логістичним забезпеченням Збройних Сил України.

Ключові слова: система логістики; комплексна автоматизована система управління; логістична діяльність; логістика; автоматизація процесів.
\end{abstract}

Постановка проблеми. Як підкреслено в [1] одним із пріоритетних завдань оборонної реформи є створення ефективної системи управління Збройними Силами України як основи системи управління силами оборони держави. Одночасно 3 реалізацією заходів, пов'язаних 3 безпосереднім реформуванням оборонного відомства, важливим в реалізації цього завдання $є$ впровадження в діяльність органів військового управління (ОВУ) та військ (сил) сучасних інформаційних технологій, адаптація найкращих практик i підходів провідних країн-членів НАТО, комплексна автоматизація процесів оперативного (бойового) управління, зв'язку, розвідки i спостереження (C4ISR) та управління оборонними ресурсами (DRMS).

Одним 3 напрямів комплексної автоматизації основних процесів управління 3С України $\epsilon$ створення автоматизованої системи управління логістичним забезпеченням ЗС України (АСУ ЛЗ ЗС України). Створення АСУ ЛЗ ЗС України безпосередньо впливає на дотримання основних принципів логістичного забезпечення, зокрема, на пріоритетність, ефективність, гнучкість, прозорість, координацію, співробітництво, функціональну сумісність і стійкість [2].

Недостатня ефективність нинішньої системи ЛЗ - неприпустимо довгий цикл проходження інформації про предмети постачання, інфраструктуру ЛЗ, особовий склад і фінансові операції, що призводить до недостатньо обгрунтованих управлінських рішень на всіх рівнях через систематичну затримку та неузгодженість даних про поточний, перспективний та сценарний стан оборонних ресурсів.

Управління компонентами та підсистемами ЛЗ, розподіл обов'язків між учасниками логістичного ланцюга, врахування наявних ресурсів, запланованих згідно з планом надходження, а також очікуваних витрат i прогнозованих втрат, забезпечення командування інформацією про ресурси в умовах ведення бойових дій (БД), коли оперативна ситуація змінюється динамічно, безперервно та в умовах активної протидії противника здійсненню безперебійного постачання 3 використанням кібератак, дезінформаційних та інформаційнопсихологічних атак на військовослужбовців i цивільне населення, потребують використання найсучасніших методів і засобів військової логістики та надійних інформаційних технологій для скорочення циклу ЛЗ і отримання переваги над ворогом під час операції.

Загроза початку конвенційної війни з РФ у випадку нерозв'язання нею задачі ліквідації української державності методами гібридної війни та потенційна загроза застосування зброї масового ураження ще більше загострює актуальність створення й удосконалення АСУ ЛЗ ЗС України, яка має поєднувати переваги централізованих, децентралізованих та автономних інформаційних підсистем управління.

Аналіз останніх досліджень та публікацій. Джерело [3] надає відомості про приклади впровадження IT-проектів в оборонних відомствах та дані про використані програмної платформи ERP-класу. У роботі [4] наведено окремі аспекти, які мають значення 
для успішної реалізації IT-проектів великого масштабу. Наводяться дані про потерпання урядового сектору від помилок програмних кодів, зокрема оборонного відомства США та інших країн незважаючи на астрономічні бюджети 3 розроблення ОВТ і спеціального програмного забезпечення (СП3) [5-7].

Метою статті $\epsilon$ висвітлення ключових тенденцій інформатизації ЛЗ збройних сил провідних країн світу, актуальних проблем інформатизації МО України та ЗС України і формулювання підходів до процесу інформатизації Л3 ЗС України з врахуванням проблемних питань та досвіду.

Виклад основного матеріалу. Світова тенденція зі створення великомасштабних автоматизованих систем управління оборонними ресурсами в країнахчленах НАТО та інших розвинутих країнах бере свій початок із другої половини 90-х років 3 автоматизації процесів управління взаємопов'язаних функціональних сфер у межах окремих програмно-технічних рішень (ПТР) та подальшої передачі даних на нові програмно-апаратні платформи, або інтеграції ПТР попередніх поколінь за допомогою використання інтеграційних програмних рішень в єдину інформаційну систему 3 використанням програмних платформ класу ERP. Подальший розвиток концепцій архітектури інформаційного середовища та стрімкий розвиток програмних i апаратних засобів зробив можливим завершення життєвих циклів програмних систем попередніх поколінь 3 повним переходом даних про оборонні ресурси в єдине інформаційне середовище на базі сучасних ERP-систем. Система такого класу об'єднує в єдиному програмному середовищі та інформаційному просторі найважливіші процеси логістичного забезпечення та повсякденної діяльності, розвитку i застосування збройних сил (оборонне планування, управління логістикою, фінансами, оргструктурою та особовим складом, технічним обслуговуванням та ремонтом обладнання, інфраструктурою) i створює можливість для побудови інформаційно-аналітичних систем і систем підтримки прийняття рішень [3].

Сучасні автоматизовані системи логістичного забезпечення сил оборони країнчленів НАТО створюються відповідності до вимог щодо функціональності, архітектури, процесів, процедур і стандартів НАТО i враховують основні принципи сучасних військових логістичних концепцій [8].
Погляди командування 3С США щодо завдань, які мають виконувати АСУ ЛЗ сформовані 3 огляду на принципи i загальну концепцію логістики операцій [9] та досягнення інформаційних технологій. До основних принципів логістики, дотримання яких має забезпечити ЗС США оперативну доступність, глибину і тривалість бойових дій, свободу дій командування і довгу витривалість необхідну для рішучих дій, входить:

інтеграція - об'єднує усі елементи логістичного забезпечення, що забезпечує злагодженість командування силами;

прогнозування - вміння передбачити вимоги операції до забезпечення, не очікуючи повного чи часткового замовлення;

реактивність - здатність швидко реагувати на зміну вимог до логістичного забезпечення та правильно відповідати на потреби у підтримці у потрібному місці в певний час;

простота процесів i процедур процесів логістичного забезпечення;

економність - підтримка ресурсів, які може використовувати командування для досягнення максимально можливого ефекту;

живучість - здатність захистити персонал, ОВТ і запаси;

безперервність - досягається системою інформаційно інтегрованих мереж, що об єднують елементи логістики, управління персоналом і медичної підтримки операцій;

імпровізація - спроможність до адаптації логістичного забезпечення до несподіваних ситуацій під час операції.

Відповідно до цих принципів функціональність АСУ ЛЗ має відповідати таким вимогам:

централізація інформації про потреби бойових підрозділів у матеріалах і засобах (Мт3);

забезпечення доступу до постійно обновлюваної інформації від різних джерел централізованої бази даних логістичного забезпечення (відстеження запасів, стану i місця розташування боєприпасів, ПММ та іншого майна);

планування логістичного забезпечення на тактичному, оперативному та стратегічному рівнях;

взаємодія 3 постачальниками Мт3 i підрядниками 3 доступом посадових осіб до постійно підтримуваної загальної бази забезпечення i системи електронного моніторингу руху предметів постачання;

взаємодія й інтеграція інформації об'єднаних і видових систем забезпечення 
збройних сил, включаючи систему постачання зброї і матеріальних засобів, фінансового, медичного, технічного забезпечення i перевезення;

взаємодія процесів забезпечення угруповань сил і оперативного управління ними, а також надання можливості командуючим оперативними формуваннями вибору з більшого числа тактичних варіантів дій;

взаємодія інформаційних систем логістики країн-членів НАТО, а також союзників США, під час спільного врегулювання конфліктів і криз.

Кінцевою метою є створення єдиної, адаптивної, синхронізованої інформаційної інфраструктури системи логістичного забезпечення бойових дій у децентралізованих "мережецентричних" умовах.

Військове відомство удосконалення, підтримку нинішніх інформаційних систем i розроблення нових здійснює астрономічні витрати [5-6], проте, інформатизація процесів управління оборонними ресурсами, військами та ОВТ $є$ i продовжує бути пріоритетним напрямом. Створення нових i модернізація нинішніх компонентів АСУ ЛЗ США на основі передових інформаційних технологій, використання виконавцями кращих практик проектного менеджменту та залучення постачальників інформаційних сервісів 3 одночасним посиленням кібербезпеки [11] дає змогу підвищити ефективність управління тилом ЗС США, скоротити час на отримання i всебічне оцінювання відомостей про Мт3 на всіх етапах їх руху від планування до використання або експлуатації під час застосування ЗС США, підвищити ефективність кадрового, медичного i фінансового забезпечення, а також поліпшити взаємодію 3 аналогічними системами союзників.

Цілком логічним

рішенням

командування 3С США та ЗС інших країнчленів НАТО було впровадження i застосування підходів до планування та управління оборонними ресурсами, які реалізовані у системах ERP-класу 3 доопрацюванням постачальниками індустріальних програмних платформ програмними рішеннями, що реалізують особливості управління особовим складом, формування оргструктур збройних сил та контингентів і планування операцій. 3С США використовують програмні рішення ERPкласу (SAP, Oracle, Peoplesoft), ЗС Великої
Британії (Oracle, IFS), 3C Канади (SAP, Peoplesoft), Бундесвер (SAP) тощо. Різноманітність постачальників пояснюється різними підходами до вибору програмної реалізації окремих функціональних сфер i різною готовністю постачальників програмних рішень задовольнити потреби військових організацій. Зокрема, в США нині діє програма створення цілком інтегрованої ЕRР-системи логістичного забезпечення 3 побудовою єдиного віртуального органу логістики (Joint Logistics Enterprise) на базі технологіi корпоративного сховища даних (EDW Enterprise Data Warehouse) та інтеграції різнорідних інформаційних систем успадкованих з 90-х та початку 2000 років.

Моніторинг діяльності МО України та 3С України проведений у 2016-2018 роках, виявив низку проблем під час здійснення логістичного забезпечення ЗС України та заходів автоматизації процесів логістики, а саме:

1. Відсутність об'єднаної системи логістики, недосконалість системи управління Л3 ЗС України не давала змоги на високому рівні здійснювати ЛЗ;

2. Неоптимальний

розподіл відповідальності та повноважень щодо організації ЛЗ в структурах ОВУ Міністерства оборони України та Генерального штабу ЗС України, що знижувало ефективність системи логістичного забезпечення і системи управління в цілому, передбачається подолати шляхом організації структур планування ЛЗ (Головне управління логістики), структур забезпечення (Тил, Озброєння) та структур управління силами і засобами оперативної логістики (Командування сил логістики);

3. Недостатній рівень постачання ресурсів для забезпечення заходів щодо розвитку, підготовки та застосування військ (сил) у поєднанні 3 надмірністю обсягів, неактуальністю нормативно-правової бази в умовах особливого періоду призводили до зниження боєздатності військ (сил);

4. Відсутність інтегрованої АСУ Л3 ЗС України значною мірою не давала змоги використовувати знання та управлінський досвід командування на всіх рівнях управління, можливості сил i засобів ЛЗ, раціонально керувати матеріально-технічними та іншими ресурсами i, як наслідок, обмежувала оперативність реагування військ (сил) на загрози та обмежувала можливості виконання бойових завдань;

5. Незадовільний рівень застосування в ОВУ сучасних інформаційних технологій, 
програмних i технічних рішень. Наявних елементів автоматизації ЛЗ недостатньо для забезпечення автоматизованої підтримки завдань обліку предметів постачання та оперативного планування ЛЗ. Відсутність інтегрованої АСУ ЛЗ ЗС України призводила до застосування спрощених методів управління складними системами, заснованих на інтуїції та особистому досвіді i діючій нормативній базі управлінських рішень, які спрямовувались на розв'язанні окремих поточних задач.

6. Заходи щодо автоматизації процесів управління ЛЗ ЗС України станом на 2018 рік мають фрагментарне та несистематичне ресурсне забезпечення. Нормативне регулювання діяльності зі створення АСУ базується на стандартах, що незабаром стануть неактуальними через практично завершений процес гармонізації державних стандартів 3 міжнародними у сфері програмної інженерії і настанням “перехідного періоду”. Станом на 2018 рік дослідно-конструкторські роботи щодо створення єдиної інформаційної системи, спроможної підтримати життєвий цикл предметів постачання під час Л3 ЗС України від стадії оборонного планування до інтеграції на інформаційному рівні 3 автоматизованими системами управління військами (АСУВ) у процесі застосування військ і до утилізації та відчуження надлишкового військового майна, не проводились, хоча наукове обгрунтування, планування та підготовка до таких робіт шляхом включення в державне оборонне замовлення здійснювались.

Таким чином, $\epsilon$ ризик невиконання у повному обсязі до кінця 2020 року завдань Стратегічного оборонного бюлетеня 1.4.6 щодо інтеграції АСУВ, як складових перспективної системи C4ISR, із системою управління оборонними ресурсами та 1.4.8 щодо створення єдиної інформаційної системи управління оборонними ресурсами, яка комплексно охопить весь ланцюг ЛЗ.

Шлях вирішення завдань Стратегічного оборонного бюлетеня зі створення та удосконалення АСУ ЛЗ 3С України має враховувати досвід провідних країнчленів НАТО, поточний стан інформаційних систем, що підтримують окремі складові життєвого циклу оборонних ресурсів, перспективні розробки та плани щодо розгортання удосконалених i нових інформаційних систем.

Досвід провідних країн-членів НАТО щодо автоматизації ЛЗ свідчить про широке використання багатофункціональних систем класу ERP, адаптованих постачальниками програмно-апаратних рішень та їх партнерами до рівня галузевих рішень для організацій сектору безпеки і оборони.

Урахування світового досвіду, дотримання Основних положень логістичного забезпечення ЗС України, затверджених наказом МОУ № 522 від 11.10.2016, Концепції відомчих програм створення ЄАСУ ЗС України, єдиної інформаційної системи управління оборонними ресурсами та інформаційної інфраструктури на період до 2020 року, затвердженої Міністром оборони України 12.05.2018 [12] під час створення та удосконалення АСУ ЛЗ ЗС України як складової ЄАСУ ЗС України дасть змогу досягти таких цілей:

повної ситуаційної обізнаності ОВУ на всіх рівнях про логістичні ресурси (повноцінне охоплення ресурсів, оперативне відстеження наявності, місця розташування матеріальних запасів i засобів ї доставки) у режимі реального часу на основі єдиної бази даних та інформаційно-комунікаційного простору;

своєчасного реагування на поточні та прогнозовані потреби угруповань сил (ситуаційна адаптивність), швидкої та адресної доставки і розподілу засобів забезпечення 3 відмовою від завчасного створення значних запасів засобів логістичного забезпечення;

підвищення боєготовності військ (сил) та ресурсного забезпечення БД протягом тривалого часу;

повної інтеграції заходів 3 управління ресурсами і засобами ЛЗ під час бойових дій (операцій);

ефективного i передбачливого

планування процесів технічного обслуговування i ремонту, забезпечення експлуатаційної надійності та ремонтопридатності;

скорочення термінів ремонту, обслуговування/модернізації озброєння, військової техніки та матеріальних засобів, зменшення обсягів потрібних запасних частин i майна;

досягнення найбільшої однорідності процесів функціонування АСУ ЛЗ як в режимі мирного, так і воєнного часу;

взаємодії із зовнішніми $\mathrm{AC}$ та інформаційними системами через інтеграційні шлюзи та підвищення рівеня інтероперабельності від 2 до 3 відповідно до Доктрини комунікаційних та інформаційних систем союзницьких формувань АJP-6 [10]. 
Вважаємо доцільним досягти значного скорочення термінів створення АСУ ЛЗ ЗС України на основі використання вже наявного досвіду провідних країн i країнчленів НАТО; зменшення проектних ризиків шляхом урахування чинників успіху проектів [4]; використання апробованих систем ERPкласу, що мають відповідні екосистеми підтримки, значний проектний досвід в секторі безпеки i оборони та кадровий потенціал.

Навіть із урахуванням несприятливих фінансових, технологічних i нормативних чинників, необхідно невідкладно здійснювати дослідно-конструкторські розробки зі створення АСУ ЛЗ ЗС України на базі сучасних програмно-апаратних платформ і у процесі робіт вжити заходи щодо попередження ризиків і подолання проблем: недостатньої зрілості кадрового забезпечення з боку оборонного відомства у сфері проектного менеджменту та програмної інженерії;

невизначеності та ризиків перехідного періоду відходу попередніх і настання дії нових нормативних документів зі створення програмних систем;

фрагментарності та недостатньої інтегрованості/інтероперабельності наявних локальних інформаційних систем;

організаційної невизначеності і кадрової незабезпеченості надійної системи підтримки інформаційних систем управління оборонними ресурсами.

Функціональну архітектуру АСУ ЛЗ ЗС України пропонується реалізувати на базі комплексів засобів автоматизації (КЗА), які необхідно розподілити за рівнями управління та обсягами доступу до інформації на три групи - тактичну, оперативну, стратегічну. Кожний різновид КЗА має надавати можливість користувачам залежно від повноважень виконувати свої функції в одному з чотирьох компонентів інформаційної підтримки Л3, зокрема, при застосуванні 3С України, здійсненні повсякденної діяльності, мобілізації та оборонному плануванні.

Спільними для усіх компонентів АСУ Л3 ЗС України є функціональні сфери (модулі):

"Інформаційно-аналітичне забезпечення логістики”;

“Закупівельна логістика";

"Матеріальне забезпечення";

"Відновлення ОВТ";

“Транспортна логістика";
"Інженерно-інфраструктурне

забезпечення";

"Кодифікація";

"Управління надлишковим військовим майном";

"Керування життєвим циклом майна".

Компонент, що використовуеться під час застосування військ $є$ ключовим для оцінювання ефективності діяльності всього ланцюга ЛЗ у підтримці виконання ЗС України першочергової задачі - збройної відсічі агресору і звільнення окупованих територій. Цьому компоненту потрібно мати КЗА 3 можливістю інформаційної взаємодії 3 додатковими програмними модулями (інтерфейси із СПЗ та/або автоматизованими системами управління військами), які забезпечують комплексне розв' язання задачі підготовки військ до ведення БД, планування бойових операцій, синхронізації дій командування. Такими об' єктами взаємодії, зокрема, мають бути модулі:

“Організації роботи штабів та ОВУ”;

"Інформаційного обміну";

"Ведення і відображення оперативної та логістичної обстановки за допомогою геоінформаційних технологій”;

"Електронного документообігу" на ПУ;

"Навчання та тренування".

Компонент підтримки повсякденної діяльності спрямований на інформаційну підтримку виконання функціональних процесів:

КЗА тактичного рівня (у підрозділах): поточний облік ОВТ і Мт3 та складський облік;

підтримка процесів руху, списання i утилізації ОВТ і Мт3. ланці):

КЗА оперативного рівня (У середній

аналіз i прогноз витрат матеріальних засобів підлеглими підрозділами;

складання планів постачання (відповідно до предметів постачання);

складання звітності i надання узагальненої інформації про логістичну діяльність підлеглих підрозділів і виду збройних сил загалом - фінансові показники $\mathrm{i}$ інші показники логістичної діяльності, динаміка і тенденції їх змін;

контроль виконання розпоряджень вищого керівництва щодо логістичної діяльності. рівні):

КЗА стратегічного рівня (на верхньому

розрахунки потреби в ОВТ і Мт3, підтримка процесів постачання і закупівлі OBT; 
аналіз діяльності складових відомства витрати і виконання плану;

аналіз фінансової діяльності відомства основні фінансові показники, динаміка i тенденції їх змін, взаєморозрахунки;

оптимізація матеріальних, фінансових i інформаційних потоків, реальна оцінка вартості логістичних операцій;

складання узагальненої звітності і надання інформації про логістичну діяльність відомства загалом вищому керівництву держави - для формування бюджетного запиту.

КЗА стратегічного рівня мають забезпечити використання та відображення оперативних даних, отримувані в режимі реального часу 3 оперативних систем, що автоматизують основні види діяльності 3С України, а також інших доступних джерел даних, які можуть знадобитися під час ухвалення стратегічних рішень.

Компонент мобілізащї спрямований на інформаційну підтримку ЛЗ заходів мобілізації.

Компонент оборонного планування спрямований на інформаційну підтримку завдань довгострокового, середньострокового та короткострокового планування щодо нарощування спроможностей і реагування на загрози.

Аналітична складова верхнього рівня є програмно-технічним комплексом, що користується даними, зібраними всіма компонентами АСУ ЛЗ ЗС України. Функціями аналітичних систем $є$ збір i надання даних для аналізу по всіх видах діяльності, зокрема даних щодо стану мобілізаційних ресурсів; моніторингу рівня забезпеченості військових формувань у процесі планування операцій, що надає можливість, наприклад, сценарного аналізу під час оборонного планування; аналізу ефективності ЛЗ застосування ЗС України після завершення операції та підтримати впевненість командування у правильності прийняття рішень.

Висновки. Логістичні системи військового призначення $є$ масштабнішими i різноманітнішими системами порівняно 3 логістичними системами цивільного призначення, а саме вони $є$ ієрархічними; територіально розгалуженими та ешелонованими; гнучкими за місцями розташування i доставки; 3 підвищеними ризиками зловмисного втручання та втрат.

Практичний досвід країн-членів НАТО в області автоматизації оборонних відомств та розробки АСУ свідчить, що ключовим підходом до автоматизації процесів ЛЗ $є$ перехід від локальних програмно-технічних рішень для окремих наборів функцій на різних управлінських рівнях до інтегрованої АСУ оборонними ресурсами, що охоплює усю управлінську вертикаль від МО України та ГШ ЗС України до окремого підрозділу, військовослужбовця та працівника ЗС України.

АСУ ЛЗ 3С України має охоплювати усі види діяльності 3 урахуванням Основних положень логістичного забезпечення ЗС України і за своїм обсягом дотримуватись рекомендацій АJP-6 щодо комунікаційноінформаційних систем країн-членів НАТО.

Процес проектування та реалізації АСУ Л3 ЗС України потребує залучення підготовленого кадрового ресурсу не тільки 3 боку виконавця, a i 3 боку організаціїзамовника, дотримання стандартів проектного менеджменту систем і програмної продукції, якості створення програмної продукції, управління проектними ризиками та використання апробованих у секторі безпеки i оборони програмно-технічних рішень.

Концептуальне проектування, прототипування та реалізацію АСУ ЛЗ 3С України необхідно здійснювати 3 урахуванням необхідності досягнення інтероперабельності 3 вже наявними програмно-технічними рішеннями, що прийняті на озброєння.

Для забезпечення супроводу АСУ ЛЗ ЗС України як гетерогенної програмнотехнічної системи, необхідно дотримуватись сучасних стандартів інтеграційного, інфраструктурного, комунікаційного сервісу 3 урахуванням дотримання безпекового режиму, для чого необхідно створити відповідні організаційні структури у складі МО України 3 належним ресурсним забезпеченням i повноваженнями.

Подальші дослідження доцільно здійснювати в напрямі вивчення досвіду проектування, реалізації і підтримки автоматизованих логістичних систем країнчленів НАТО 3 огляду нормативного i ресурсного забезпечення.

\section{СПИСОК ВИКОРИСТАНОЇ ЛІТЕРАТУРИ}

1. План дій щодо впровадження оборонної реформи у 2016 - 2020 роках (Дорожня карта оборонної реформи) від 15.08.2016 Електронний ресурс]. Режим доступу: http://www.mil. gov.ua/content/tenders/Plan_2208.pdf

2. Наказ про затвердження Основних положень логістичного забезпечення Збройних Сил України 
від 11.10.2016 року № 522 [Копія] / МО України. $-\mathrm{K}$.

3. Звіт KPMG "Defense ERP overview by country" [Електронний ресурс]. - Режим доступу: https://assets.kpmg.com/content/dam/kpmg/pdf/2016 /04/defense-erp-overview-by-country.pdf

4. Витяг зі звіту CHAOS Report 2015 дослідницької компанії Standish Group [Електронний ресурс]. Режим доступу: https://www.infoq.com/articles/standish-chaos-2015

5. Квартальний огляд "Software Fail Watch 2016, Quarter One" [Електронний ресурс]. - Режим доступу:

https://www.tricentis.com/blog/2016/04/07/softwarefail-watch-2016-quarter-one/

6. Повідомлення про помилки СПЗ для управління OBT "Flying blind: F-35's radar software fails in the air. Lockheed-Martin promises patched code will soar this month. By Richard Chirgwin" [Електронний pecypc]. - Режим доступу: https://www.theregister.co.uk/2016/03/08/flying_bli nd_f35s_radar_software_fails_in_the_air/

7. Квартальний огляд "Software Fail Watch: The Politics of Software Defects, Q2, 2018" [Електронний pecypc]. - Режим доступу: https://www.tricentis.com/blog/2018/07/09/softwarefail-watch-q2-2018/

8. Логістична доктрина союзницьких формувань Allied joint logistic doctrine AJP-4(A)
[Електронний ресурс]. - Режим доступу: http://everyspec.com/NATO/NATO-ATP/AJP-

4A_DEC2003_16606/

9. Польове керівництво з логістики операцій “FM-495-Logistics Operations" [Електронний ресурс]. Режим доступу: https://www.globalsecurity.org/military/library/policy/ army/fm/4-95/fm4-95_2014.pdf

10. Доктрина комунікаційних та інформаційних систем союзницьких формувань “Allied joint doctrine for communication and information systems AJP-6" [Електронний ресурс]. - Режим доступу: http://nso.nato.int/nso/zPublic/ap/PROM/AJP6\%20EDA\%20V1\%20E.pdf

11. Повідомлення про результати роботи Cybercom "US DoD's first malware submissions to Googlebought VirusTotal is Russia-linked LoJack" [Електронний ресурс]. - Режим доступу: https://www.cso.com.au/article/649259/us-dod-firstmalware-submissions-google-bought-virustotal-russialinked-lojack/

12. Концепція відомчих програм створення Єдиної автоматизованої системи управління Збройними Силами України, Єдиної інформаційної системи управління оборонними ресурсами та інформаційної інфраструктури на період до 2020 року, затверджена Міністром оборони України 12.05.2018 [Копія] МО України. - К.

Стаття надійшла до редакційної колегії 23.09.2018

Беляченко В. В.

Педан Ф. Ф.

Романченко О. А.

Центр военно-стратегических исследований Национального университета обороны Украины имени Ивана Черняховского, Киев

Подходы к созданию и направлениям развития, совершенствования и поддержки АСУ ЛС ВС Украины с учетом опыта стран-членов НАТО

Резюме. В статье рассмотрены проблемы и пути решения задач 1.4.6 и 1.4.8 Стратегического оборонного бюллетеня на основании опыта стран-членов НАТО по созданию интегрированной автоматизированной системы управления логистическим обеспечением Вооруженных Сил Украины.

Ключевые слова: система логистики; комплексная автоматизированная система управления; логистическая деятельность; логистика; автоматизация процессов.

V. Beljachenko;

F. Pedan;

O. Romanchenko

Center for Military and Strategic Studies of the National Defence University of Ukraine named after Ivan Cherniakhovskyi, Kyiv

Approaches to the creation and direction of development, improvement and support of the automated control systems of the Armed Forces of Ukraine, taking into account the experience of NATO member countries

Resume: The article discusses the problems and ways to solve problem 1.4.6 and 1.4.8 of the Strategic Defense Bulletin based on the experience of NATO member countries in creating integrated automated logistics management systems.

Keywords: system of logistic; integrated automated management system; automated logistic management systems; logistic activity; logistic; automation of processes. 